\title{
Analysis of long-term climatic changes at Hodeidah-Yemen during the period between 1984 and 2019
}

Abkar Ali Iraqi ( $\nabla$ drabkariraqi@gmail.com )

Hodeidah University https://orcid.org/0000-0003-1538-6383

AbdAlla Mohammed AbdAlla

\section{Research Article}

Keywords: Climatic Changes, statistical analysis, Temperature Anomalies, Hodeidah, Yemen

Posted Date: September 13th, 2021

DOI: https://doi.org/10.21203/rs.3.rs-897613/v1

License: () (1) This work is licensed under a Creative Commons Attribution 4.0 International License. Read Full License 


\section{Abstract}

Yemen is one of the Arab country that is vulnerable to climate changes, and this is clear from the indicators of impact on water resources, coastal zone environments, etc. This work focuses on studying the climatic variability at Hodeidah city-Yemen during the period between 1984 and 2019 . This study aimed to characterize trends in mean monthly, seasonal and annual temperature. To attain these objectives the collected data were analyzed using both parametric (linear regression) and non-parametric (Mann-Kendall, Spearman and Sen's slope estimator tests) methods to detect the trend and the magnitudes of rates of changes of temperature over time.

Analysis of data indicates clear climatic fluctuations of temperature. The annual means of temperature during the period of study were varied between $26.9^{\circ} \mathrm{C}$ and $30.1^{\circ} \mathrm{C}$. The warmest years were observed during the more recent years of the study period ( 2005 to 2018). The increasing rate of annual temperature is about $+0.075^{\circ} \mathrm{C} /$ year, $+0.37^{\circ} \mathrm{C} / 5$ year, $+0.75^{\circ} \mathrm{C} /$ decade,$+2.53^{\circ} \mathrm{C}$, over the whole period of study $(1985$ to 2019$),+3.7^{\circ} \mathrm{C} / 50$ year and increase to $+4.85^{\circ} \mathrm{C}$ in 2050 .

On a monthly timescale, there are similar magnitudes of rates of change from December to September with highest rates in October and November. The results also showed that most months and seasons have significant positive trends in temperature and (Z- $\alpha / 2)$ values of the MK Test $>1.96$ and positive value of Sen's slope estimator indicates significant an increasing trend towards warmer years. Anomalies of temperature confirm significant increasing trends towards warmer years (2000s to 2019).

\section{Introduction}

Al-Hodeidah Governorate (Fig. 1), is located in the western part of the Republic of Yemen and extends along the Arabian side of the Red Sea, between longitudes $\left(42-43^{\circ}\right)$ and between latitudes $\left(14-16^{\circ}\right)$. Hodeidah city is the capital of Al-Hodeidah Governorate, it is located on the coast of the Red Sea, and is about226 kilometers from the capital, Sana'a.

The area of the governorate is approximately 13,500 square kilometers, according to the results of the 2004 census, reached 2,157,552 people, and the population grows annually at a rate of $3.25 \%$. Hodeidah city is the largest coastal city in the region, and is one of the major ports in Yemen with the estimated population of 1000,000 . Its population constitutes approximately $11 \%$ of the total population of the Republic of Yemen, the main activities of the population are agriculture and fishing.

The Republic of Yemen (Fig. 1) is located on the southwestern coast of the Arabian Peninsula It's land boundaries are border with Saudia Arabia in the north and Oman in the east. Yemen is considered as one of the most arid countries within this geographical area, occupying a district about 527,970 sq. kilometers.

Based on geographic of Yemen the climate is classified by 5 major systems: humid and hot coastal plain, the temperate Yemen Highlands, Yemen High Plateaus and Hadramout - Mahra Uplands, the desert interior, and the islands. Within these geographic changes, the rain varies from about $50 \mathrm{~mm}$ within the coastal plains and desert upland regions to over $1200 \mathrm{~mm}$ within the western mountainous highland region occurring in two periods, first (March-May) and second (July-September). Rain falls primarily in the spring and summer, which occur by two main mechanisms: the Red Sea Convergence and the Inter Tropical Convergence Zone. Yemen lies within the northern stretches of the tropical climatic zone and its border with the sub-tropical climate zone. The extreme variations in elevation for the most part liable for the variations in temperature and climate over the country. Mean annual temperatures vary from but $15^{\circ} \mathrm{C}$ within the highlands to $30^{\circ} \mathrm{C}$ within the coastal plains (EPA 2004).

Temperature is one amongst the foremost recognizable and telling indicators of climate change. In terms of the temperature trends of the Arabian region for the period from amount 2011-2041, (UNEP/ROWA 2015) report indicated that both the average and maximum scenarios are projecting almost similar changes in temperature, in the range of $0-2^{\circ} \mathrm{C}$, on long term throughout $2041-2070$, the maximum scenarios exhibit temperature changes rising by up to $3-$ $4^{\circ} \mathrm{C}$ and $1-2^{\circ} \mathrm{C}$ with the average scenario. The notes issued by RICCAR (2013) in Arab region also clarified the temperature increase over for the different time periods, will rise compared to the reference period $1985-2005$. In mid-century temperatures increase to $1.7^{\circ} \mathrm{C}-2.6^{\circ} \mathrm{C}$, while at the end of $21 \mathrm{st}$ century, it will increase to $3.2^{\circ} \mathrm{C}-4.8^{\circ} \mathrm{C}$. Al-jibly (2018) referred to a scenario of climate change for future of Yemen in 2050 in the Third National Communication to the Conference of the Parties of United Nations Framework Convention on Climate Change (2018). The report indicated that all areas of Yemen will get warmer, more so in the cold winter months. There are expected rise in annual and seasonal mean temperature in all parts of Yemen with quite consistent in 2050. Annual mean temperature will rise to with an average of $2^{\circ} \mathrm{C}$ in 2050. In winter season, the temperature rise seems larger than other seasons with an average of $2.3^{\circ} \mathrm{C}$, while in summer will be the lowest increase with an average of $1.9^{\circ} \mathrm{C}$.

Several studies published by Ali and Alkadasi (2011) indicated that the effects of climatic changes can be summarized in the following:

RoY (2001) identified the vulnerable sectors as water resources; agriculture; and coastal zones. NAPA (2008) showed the major impacts of climate change in Yemen, which includes the increased water scarcity and reduced water quality; increased drought frequency, increased temperatures, and changes in precipitation patterns; deterioration of habitats and biodiversity; reduced agricultural productivity; increased sea levels; increased climatic variability; and impacts on coastal zones. WorldBank (2010) indicated to that climate change impacts on the water balance in Yemen. Elasha (2010) revealed that Yemen is highly vulnerable to climate changes that induced increased water scarcity and reduced water quality. Also, according to the IPCC third assessment report, MENA published in (Ali and Alkadasi 2011) report, which is considered Yemen is one of the regions, which is most vulnerable to the impacts of climate change on water resources, and it is considered among the regions with the highest level of water scarcity in the world. RoY (2013) indicated that water resources are considered perhaps the most vulnerable sector to climate change in Yemen. On the other hand, according to the (WorldBank 2010) the flooding was clearly observed in 1996 and during the period 2005-2008. UNDP hinted at the weakness in climate change projections and predictability at the national and local levels in Yemen due to a lack of capabilities in climate analysis and interpretation. 
All previous reports and studies referred to the impact of climate change in Yemen, while the long-term analysis and study of weather elements as an indicator to prove the climate changes are almost rare due to unavailability of historical data. Therefore, the major objective of this study is to investigate the variability of temperature, detection of significant trends and evaluate the increase of it an addition to showing the anomalies in the monthly, seasonal and annual climatic conditions in the Hodeidah city over the last 35 years. Studies fluctuation of temperature is as an indicator of climate changes in one governorate of Yemen during the period between 1984 and 2019, to helping decision makers, interested in human services and development to presenting projects that limited the problems with it.

\section{Data And Methods Of Analysis}

Monthly temperature data used in this study was provided by Meteoblue AG - Switzerland as hourly time-series for 35 years from 1985 to 2019 , this historical data are simulation for Hodeidah Airport Station, with high precision and more precise than the observational data from the airport station, which is located at more than $10 \mathrm{~km}$ away from the Hodeidah coast [www.meteoblue.com]. Weather data and model simulations for more than 30 years (from 1985 onwards) offers via Meteoblue-Data.org for climate information on it's website. This data gives a good view of the expected weather and climate patterns (temperature, rainfall, sunshine, wind speed and direction). A spatial resolution of the simulated weather data has about $30 \mathrm{~km}$. In temperature analysis, a 5 -year running average was used. The moving average or running mean is used in looking at noisy sequence data of the series (Sneyers 1992). Moving averages used to smooth out short-term fluctuations in a time series and still preserving the slowly varying trend. This technique applied to long-term time series to remove the fine-grained change between time steps. To characterize climate oscillation, we prepare air temperature data done by calculating monthly mean, seasons mean and annual mean of daily historical weather data. The seasons were determined according (Douabul and Haddad 1999), as winter (December-March; spring (April-May); summer (June-September); and autumn (October-November).

A temperature anomaly is the difference from an average, or baseline temperature. The baseline temperature is typically computed by averaging 30 or more years of temperature data (the base period of data study 1985 to 2019). When the observed temperature is higher than the baseline temperature, the positive anomaly will be occur, the opposite of that shows negative anomalies. Climate oscillation can be described by linear trend analysis of that. In time series analysis, linear regression (parametric method) to identifying linear trend to obtain the slope of hydro-meteorological variables on time. Based on linear regression the positive/negative values of the slope show increasing/decreasing trend. The advantage of the linear regression method provides a measure of significance and gives the magnitude of the rate of change based on the hypothesis test on the slope (Hirsch et al. 1991).

In this study, both parametric (linear regression) and non-parametric (Mann-Kendall ,Spearman and Sen's slope estimator tests) methods were used to detect the temperature trends, so the simplicity of the parametric method is distinguished from others (Mosmann et al. 2004).

The Mann-Kendall test is a non-parametric test for identifying trends in time series data, various researchers considered this test (Burn 1994; Douglas et al. 2002; Yue and Hashino 2003; Burn et al. 2004; Lindström and Bergström 2004; Jain and Kumar 2012; Panda and Sahu 2019) one of the best methods and used for analysis and ascertains statistical significance by hypothesis test of hydrological variables. The Mk trend test is used to perceive statistically significant decreasing or increasing trend in long term temporal data. According to this test based on two hypotheses; one is null $\left(\mathrm{H}_{0}\right)$ assumes that there is no trend (the data are independent and randomly ordered) and the other is the alternate $\left(\mathrm{H}_{1}\right)$ hypothesis elucidate significant rising or declining trend in temperature data. Positive/negative values of $Z_{M K}$ indicate increasing/decreasing trends in the time series. The null hypothesis is rejected when $\left|Z_{M K}\right|>Z_{1-a / 2}$, and a significant trend exists in the time series. $Z_{1-a / 2}$ is the critical value of $Z$ from the standard normal table, for $5 \%$ significant level the value of $Z_{-a / 2}$ is 1.96 (Shadmani et al. 2012). On the basis of $5 \%$ significance level, if $p$ Value is $\leq a=0.05$, then the alternative hypothesis is accepted, which signifies the presence of trend in the data, the absence of trend in the data showed if the $p$ Value is $\geq a=0.05$ then $\mathrm{H}_{0}$ will be accepted that denotes. Sen's slope estimator (Sen 1968) using a nonparametric method can be used to determine the magnitude of a trend of temperature in a time series. The true slope of an existing trend estimated to an amount of change per year. An upward or increasing trend indicated by positive value of Sen's slope and a negative value gives a downward or decreasing trend in the time series (Sen 1968; Da Silva et al. 2015; Dawood 2017; Tabari et al. 2011)". Sen's slope is considered better to detect the linear relationship as it is not affected by outlier in the data (Gilbert 1987). For this test have some advantage, the data need not conform to any particular distribution, but due to inhomogeneous time series the other advantage of the Sen's slope test is its low sensitivity to abrupt breaks (Jaagus 2006). (Mann 1945) \& (Kendall 1956) used this test and subsequently derived the test statistic distribution.

\section{Results And Discussions}

To study climate oscillation during long-term period of this case study, we are calculating monthly mean, seasonal mean, annual mean and anomaly mean temperature of daily historical weather data. (Fig. 2:4) shows time series of monthly, seasonal and annual mean of temperature for Hodeidah city during the period 1985-2019 and trend analysis using a linear regression model. The slope of the regression line in figures shows the rate of temperature change, also a 5-year running average was added to the time series to remove the fine-grained variation between steps. Descriptive statistics of daily temperature are calculated and given in (Table.1) including: mean, standard error, median, standard deviation (SD), sample variance, kurtosis, skewness, range, minimum and maximum.

An estimated trend was shown in (Table.2) also presented via a curve line in (Fig. 5) and show the variability of trend values during the months, seasons and annual of the study period. The results of parametric (Linear model) and non-parametric models are shown in (Table.3) were used to assess and test the temperature oscillation of monthly, seasonal and annual means. Parametric model is done using the least squares method, the magnitude of the trends was derived from the slope of the regression trend line and Sen's Slope Estimator, while the statistical significance was determined by the Mann-Kendall and Spearman correlation coefficient test Sneyers (1990). Temperature anomalies relative to the base period of data study during 1985 to 2019 were estimated and used trend analysis of monthly, seasonal and annual mean anomaly shown in (Fig. 6:8) to determine warm and cold period. 


\subsection{Mean Temperature analysis}

Table.1 shows descriptive statistics of monthly air temperature during the study period. There is clear variability of temperature between months of the year, the monthly mean of temperature changes between highest value occurred in July and August is $32.5^{\circ} \mathrm{C}$, they are considered warmest months, while the coldest month with the lowest value in January is $23.7^{\circ} \mathrm{C}$. The lowest and highest mean monthly temperature between $1985-2019$ occurred in January 1986 is $21.6^{\circ} \mathrm{C}$ and August 2015 is $34.9^{\circ} \mathrm{C}$ respectively. The mean seasonal variation between $24.9^{\circ} \mathrm{C}$ in winter and $32.2^{\circ} \mathrm{C}$ in summer, the lowest mean seasonal is $23.5^{\circ} \mathrm{C}$ in winter 1988 and the highest is $33.9^{\circ} \mathrm{C}$ in summer 2017 . The annual mean temperature during period of study is about $28.6^{\circ} \mathrm{C}$, it is varied between $26.9^{\circ} \mathrm{C}$ and $30.1^{\circ} \mathrm{C}$. The behavior of annual mean presented in (Fig. 5.a), it shows the gradual increasing of temperature from 1985 to 2019 with intense a sharp drop at 2004 , consequently the year 2004 was the coldest period, with $26.9^{\circ} \mathrm{C}$ while the warmest years occurred in the recent years from 2005 to 2018 , after that, at 2019 during the months from June to November, the monthly averages decrease sharply.

\subsection{Statistical trend analysis using the parametric method}

Table. 2 shows the magnitude of rates of temperature and (Fig. 5.b) shows the trend of monthly, seasonal and annual mean temperature for the Hodeidah city over the period 1985-2019 using a linear regression with the a 5-year smoothing curve. It's the trend of temperature toward a warmer climate, it clears that a positive trend for all months and seasons. The increasing rate of annual temperature was calculated. It is about $0.075^{\circ} \mathrm{C} /$ year, with an estimated increase $(+$ $0.37^{\circ} \mathrm{C} / 5$ year; $+0.75^{\circ} \mathrm{C} /$ decade; $+2.53^{\circ} \mathrm{C}$, over the whole period 1985 to $2019,+3.7^{\circ} \mathrm{C} / 50$ year and increase $+4.85^{\circ} \mathrm{C}$ in 2050 . On a monthly timescale, it was observed that the mean monthly temperature has a similar an increase rate from December to September $\left(0.06-0.09^{\circ} \mathrm{C} / \mathrm{year}\right)$ with the greatest increases in October and November among $\left(0.11-0.13^{\circ} \mathrm{C} /\right.$ year). It follows that on a seasonal timescale, temperatures have a similar rise in spring, summer and winter with the greatest increase in autumn $\left(1.13^{\circ} \mathrm{C} /\right.$ decade year). Magnitude of trend on monthly and seasonal timescale is presented with the trend curve in (Fig. $\left.5 . \mathrm{b}\right)$. It seems likely that the positive trend found in summer and greatest increase in autumn may be causing alterations in the length of warm period. The results of the trend of temperature concur with noted over the Arab region compared to the reference period 1985-2005 (RICCAR 2013).

\subsection{Anomaly of air temperature analysis}

The anomalies of temperature relative to the base period 1985-2019 of monthly, seasonal and annual are shown in (Fig. 6:8) with the a 5-year smoothing curves, together with linear trend was calculated. The behavior of anomalies air temperature followed a similar pattern from January to December and four seasons. The general pattern of anomalies change is dominated by negative values from 1985 to the period during 2000 s, and it is noticed that, with positive values within some years. Whereas the positive values are fully dominated after 2000 s to 2019 with the exception of July, August and September months, it is obvious that negative values are encountered during 2019. In general, the positive trend line for all months, season and annual time series noticed after the 2000s, and an accelerated warming trend occurred after 2010. Moreover, the values of anomalies were larger in autumn than other three seasons. It seems likely that the larger values of positive anomalies noticed in autumn may be due to the length of summer months comparing than those representing autumn months (i.e. increasing the time span of the warm period). Based on anomalies variations, we can distinguish a cool period to be from 1985 to 2000 s, while the period after 2000 s to 2019 is considered a warm period. This is due to the length of the summer months compared to the autumn months.

Table.1: Statistical summary of monthly, seasonal and annual temperatures for Hodeidah city during the period from 1985-2019.

\begin{tabular}{|c|c|c|c|c|c|c|c|c|c|c|c|c|c|c|c|c|}
\hline Time & JAN & FEB & MAR & APR & MAY & JUN & JUL & AUG & SEP & OCT & NOV & DEC & SPRING & SUMMER & AUTUMN & WINTER \\
\hline Mean & 23.7 & 24.7 & 26.8 & 29.4 & 31.2 & 31.9 & 32.5 & 32.5 & 31.8 & 28.5 & 25.8 & 24.2 & 30.3 & 32.2 & 27.1 & 24.9 \\
\hline Std E & 0.2 & 0.2 & 0.2 & 0.2 & 0.2 & 0.2 & 0.2 & 0.2 & 0.2 & 0.2 & 0.3 & 0.2 & 0.2 & 0.2 & 0.2 & 0.2 \\
\hline Median & 23.8 & 24.7 & 26.9 & 29.2 & 31.1 & 31.9 & 32.4 & 32.6 & 31.5 & 28.4 & 25.6 & 24.1 & 30.1 & 32.0 & 26.9 & 24.8 \\
\hline S.D & 1.0 & 1.0 & 1.0 & 1.0 & 1.1 & 0.9 & 1.2 & 1.2 & 1.0 & 1.3 & 1.6 & 1.3 & 1.0 & 1.0 & 1.4 & 0.9 \\
\hline S.V & 1.1 & 1.0 & 1.0 & 1.0 & 1.2 & 0.8 & 1.4 & 1.3 & 1.0 & 1.7 & 2.4 & 1.6 & 1.0 & 0.9 & 1.8 & 0.8 \\
\hline Kurtosis & -0.7 & -1.3 & 0.0 & 0.0 & -0.3 & 0.0 & -0.5 & 0.0 & -0.3 & -0.8 & -1.2 & -0.9 & -0.5 & -0.1 & -1.0 & -1.1 \\
\hline Skewness & -0.1 & 0.1 & -0.1 & 0.6 & 0.0 & 0.0 & 0.2 & -0.2 & 0.1 & 0.2 & 0.2 & 0.2 & 0.2 & 0.1 & 0.4 & 0.3 \\
\hline Range & 4.0 & 3.4 & 4.4 & 4.2 & 4.9 & 4.1 & 4.6 & 5.0 & 4.0 & 4.9 & 5.1 & 4.6 & 3.9 & 4.1 & 4.4 & 3.2 \\
\hline $\begin{array}{l}\text { Min of } \\
\text { mean }\end{array}$ & 21.6 & 23.1 & 24.6 & 27.6 & 28.7 & 29.6 & 30.1 & 29.9 & 29.5 & 26.0 & 23.2 & 22.1 & 28.3 & 29.8 & 25.2 & 23.5 \\
\hline $\begin{array}{l}\text { Max of } \\
\text { mean }\end{array}$ & 25.6 & 26.5 & 29.0 & 31.8 & 33.6 & 33.7 & 34.7 & 34.9 & 33.5 & 30.9 & 28.3 & 26.7 & 32.2 & 33.9 & 29.6 & 26.6 \\
\hline
\end{tabular}

Table.2: The magnitude of rates of temperature over monthly, seasonal and annual time scales. 


\begin{tabular}{|lllllll|}
\hline Month & Trend/year & Trend/5year & Trend/10year & Trend/Over Whole period & Trend/50year & Trend/in 2050 \\
\hline Jan & 0.08 & 0.38 & 0.77 & 2.69 & 3.84 & 4.99 \\
\hline Feb & 0.06 & 0.32 & 0.64 & 2.24 & 3.21 & 4.17 \\
\hline Mar & 0.05 & 0.23 & 0.46 & 1.62 & 2.31 & 3.00 \\
\hline Apr & 0.06 & 0.28 & 0.56 & 1.95 & 2.79 & 3.63 \\
\hline May & 0.07 & 0.37 & 0.74 & 2.60 & 3.72 & 4.83 \\
\hline Jun & 0.06 & 0.30 & 0.60 & 2.09 & 2.98 & 3.88 \\
\hline Jul & 0.07 & 0.37 & 0.73 & 2.57 & 3.67 & 4.77 \\
\hline Aug & 0.06 & 0.31 & 0.63 & 2.20 & 3.14 & 4.09 \\
\hline Sep & 0.06 & 0.30 & 0.60 & 2.11 & 3.01 & 3.91 \\
\hline Oct & 0.10 & 0.49 & 0.98 & 3.42 & 4.89 & 6.35 \\
\hline Nov & 0.13 & 0.64 & 1.29 & 4.50 & 6.43 & 8.36 \\
\hline Dec & 0.09 & 0.47 & 0.95 & 3.32 & 4.75 & 6.17 \\
\hline Spring & 0.07 & 0.33 & 0.65 & 2.28 & 3.25 & 4.23 \\
\hline Summer & 0.06 & 0.32 & 0.64 & 2.24 & 3.20 & 4.16 \\
\hline Autumn & 0.11 & 0.57 & 1.13 & 3.96 & 5.66 & 7.36 \\
\hline Winter & 0.07 & 0.35 & 0.69 & 2.42 & 3.45 & 4.49 \\
\hline Annual & 0.07 & 0.37 & 0.75 & 2.61 & 4.85 \\
\hline
\end{tabular}

\subsection{Statistical tests using Non-parametric method}

The non-parametric method using (Mann-Kendall, Spearman and Sen's slope estimator) tests, these statistical tests have been widely used to demonstrate the significance of trends; it shows either increasing or decreasing trends. Moreover, estimate the magnitude of temperature can be estimated using a linear regression model and Sen's slope that mean, how much increase or decrease per year and the correlation coefficients and equations were calculated and presented in (Table.3). On the basis of $5 \%$ significance level for this test result $p$ (2-tailed) with Spearman test and $p$ value in linear regression model are less than the significance level $a=0.05$ (Burn 1994), then the alternative hypothesis is accepted which signifies the presence of trend in the time series, $\mathrm{H}_{0}$, (there is no trend), hence, the hypothesis is not accepted and rejecting $\mathrm{H}_{\mathrm{o}}$.

The results revealed the statistically significant increasing trends for all months, seasons and annual (at the $5 \%$ significant level the value of $Z_{\text {- } a / 2}$ is 1.96 (Shadmani et al. 2012), the most values of $Z_{-a / 2}$ values of the MK Test > 1.96, revealed an increasing trend in temperature. The Mann-Kendall and Spearman tests confirmed that significant positive trend with $95 \%$ confidence limit using a linear regression model except April, June and October, which occurred no trend with Mann-Kendall and positive trend with other test. The magnitude of rates of annual temperature was calculated using Sen's slope. A positive value of (Sen's slope $=0.076$ ) of the mean annual indicates an upward or increasing trend towards warmer years, these values confirmed that estimated by linear regression model. These results of non-parametric method has shown in (Table.2 \& 3). The statistically significant increasing trends during spring, summer and autumn led to increase in mean temperature, positive trend slope and positive values of anomalies starting from April to November, therefor the warm period appears to be longest time period. These results can be considered to be in agreement with those found in the WMO report (WMO 2011) on the status of the global climate in 2010 , global average temperature has varied in different time scales ranging from a few years to several decades.

Table.3: Trend analysis using non-parametric (Mann-Kendall, Spearman and Sen's slope estimator tests) and parametric (linear regression model) method 


\begin{tabular}{|c|c|c|c|c|c|c|c|c|c|c|c|c|c|c|}
\hline \multirow{3}{*}{ Methods } & \multicolumn{9}{|c|}{ Non-parametric method } & \multirow{2}{*}{\multicolumn{5}{|c|}{$\begin{array}{l}\text { Parametric method } \\
\text { linear regression model }\end{array}$}} \\
\hline & \multirow{2}{*}{$\begin{array}{l}\text { Sen's } \\
\text { Slope } \\
\text { Sen's } \\
\text { Slope }\end{array}$} & \multicolumn{4}{|c|}{ Mann-Kendall } & \multicolumn{4}{|c|}{ Spearman test } & & & & & \\
\hline & & $s$ & Z & Trend & $\begin{array}{l}\text { Significance } \\
(0.05)\end{array}$ & $r_{s}$ & Trend & p (2-tailed) & $\begin{array}{l}\text { Significance } \\
(0.05)\end{array}$ & $\begin{array}{l}\text { Regression } \\
\text { Equation }\end{array}$ & $\mathbf{R}$ & p value & Trend & $\begin{array}{l}\text { Si! } \\
\text { (0. }\end{array}$ \\
\hline Jan & 0.080 & 171 & 2.52 & + & * & 0.76 & + & 0.0000000 & * & $\begin{array}{l}Y=0.077 x \\
-129.9\end{array}$ & 0.75 & 0.0000016 & + & * \\
\hline Feb & 0.067 & 174 & 2.56 & + & * & 0.67 & + & 0.0000100 & * & $\begin{array}{l}Y=0.064 x \\
-103.6\end{array}$ & 0.67 & 0.0000092 & + & * \\
\hline Mar & 0.044 & 168 & 2.48 & + & * & 0.55 & + & 0.0006500 & * & $\begin{array}{l}Y=0.046 x \\
-65.7\end{array}$ & 0.49 & 0.0031256 & + & * \\
\hline Apr & 0.052 & 131 & 1.93 & no & * & 0.51 & + & 0.0016700 & * & $\begin{array}{l}Y=0.056 x \\
-82.3\end{array}$ & 0.58 & 0.0002689 & + & * \\
\hline May & 0.080 & 187 & 2.76 & + & * & 0.71 & + & 0.0000000 & * & $\begin{array}{l}Y=0.074 x \\
-117.6\end{array}$ & 0.68 & 0.0000066 & + & * \\
\hline Jun & 0.063 & 132 & 1.94 & no & * & 0.72 & + & 0.0000000 & * & $\begin{array}{l}Y=0.060 x \\
-87.5\end{array}$ & 0.67 & 0.0000093 & + & * \\
\hline Jul & 0.080 & 151 & 2.22 & + & * & 0.66 & + & 0.0000100 & * & $\begin{array}{l}Y=0.073 x \\
-114.4\end{array}$ & 0.63 & 0.0000432 & + & * \\
\hline Aug & 0.071 & 181 & 2.67 & + & * & 0.65 & + & 0.0000200 & * & $\begin{array}{l}Y= \\
0.0629 x- \\
93.3\end{array}$ & 0.56 & 0.0004740 & + & * \\
\hline Sep & 0.068 & 168 & 2.48 & + & * & 0.66 & + & 0.0000200 & * & $\begin{array}{l}Y=0.060 x \\
-88.7\end{array}$ & 0.63 & 0.0000533 & + & * \\
\hline Oct & 0.100 & 105 & 1.54 & no & * & 0.76 & + & 0.0000000 & * & $\begin{array}{l}Y=0.098 x \\
-167.1\end{array}$ & 0.76 & 0.0000001 & + & * \\
\hline Nov & 0.130 & 171 & 2.52 & + & * & 0.84 & + & 0.0000000 & * & $\begin{array}{l}Y=0.129 x \\
-231.9\end{array}$ & 0.85 & 0.0000000 & + & * \\
\hline Dec & 0.094 & 159 & 2.34 & + & * & 0.77 & + & 0.0000000 & * & $\begin{array}{l}Y=0.095 x \\
-165.8\end{array}$ & 0.77 & 0.0000001 & + & * \\
\hline Spring & 0.068 & 155 & 2.28 & + & * & 0.66 & + & 0.0000200 & * & $\begin{array}{l}Y=0.065 x \\
-99.9\end{array}$ & 0.67 & 0.0000098 & + & * \\
\hline Summer & 0.070 & 201 & 2.96 & + & * & 0.72 & + & 0.0000000 & * & $\begin{array}{l}Y=0.064 x \\
-96.0\end{array}$ & 0.67 & 0.0000087 & + & * \\
\hline Autumn & 0.113 & 111 & 1.63 & no & * & 0.87 & + & 0.0000000 & * & $\begin{array}{l}Y=0.113 x \\
-199.5\end{array}$ & 0.86 & 0.0000000 & + & * \\
\hline Winter & 0.070 & 144 & 2.12 & + & $\star$ & 0.77 & + & 0.00000 & * & $\begin{array}{l}Y=0.069 x \\
-113.3\end{array}$ & 0.78 & 0.0000000 & + & * \\
\hline Annual & 0.076 & 146 & 2.15 & + & * & 0.88 & + & 0.000000 & * & $\begin{array}{l}Y=0.075 x \\
-120.7\end{array}$ & 0.84 & 0.0000000 & + & * \\
\hline
\end{tabular}

Note: * Significant, + Positive, - Negative, no No trend

\section{Conclusions}

According to the reports, Yemen is vulnerable to climate change, based on that fluctuation: water resources, agriculture, and coastal zones will vulnerable to impacts of climate change caused an increased water scarcity, reduced water quality, increase the frequency and magnitude of disasters and an increase of the environmental problems. This study investigated monthly, seasonal and annual climatic fluctuation in Hodeidah city based on daily mean air temperature during the period between 1984 and 2019.

The results show the monthly mean of temperature changes between highest value is $32.5^{\circ} \mathrm{C}$ in July and August and lowest value is $23.7^{\circ} \mathrm{C}$ in January. The mean seasonal varied between $24.9^{\circ} \mathrm{C}$ in winter and $32.2^{\circ} \mathrm{C}$ in summer, while the annual mean temperature during period of study is about $28.6^{\circ} \mathrm{C}$, it is varied between $26.9^{\circ} \mathrm{C}$ and $30.1^{\circ} \mathrm{C}$. The coldest year occurred in 2004 with $26.9^{\circ} \mathrm{C}$ while the warmest years occurred in the recent years from 2005 to 2018 . The increasing rate of annual temperature is about $0.075^{\circ} \mathrm{C} /$ year, and $\left(+0.37^{\circ} \mathrm{C} / 5\right.$ year; $+0.75^{\circ} \mathrm{C} /$ decade; $+2.53^{\circ} \mathrm{C}$, over the whole period 1985 to $2019,+3.7^{\circ} \mathrm{C} / 50$ year and increase $+4.85^{\circ} \mathrm{C}$ in 2050 . On a monthly timescale, the mean monthly temperature has a similar an increase rate from December to September with the greatest rate in October and November, an increase in the length of warm period is attributed to the positive trend in summer and greatest an increase rate in autumn. A similar pattern of anomalies air temperature from January to December and four seasons, an accelerated warming trend occurred after 2010. Moreover, the values of anomalies were larger in autumn than other three seasons. Based on the anomalies of temperature a cool period was evident from 1985 to before the 2000s, while the warm period noticed after the 2000s to 2019. The alternative hypothesis is accepted which signifies the presence of trend in the time series, and the results revealed a statistically significant increasing trend for all months, seasons and annual. This results of this study are 
consistent with other researches that confirm a general warming trend and an increase in the occurrence of events (Al-jibly 2018), which referred to a scenarios of climate change for future of Yemen for 2050 which get warmer, more so in the cold winter months with annual mean temperature will rise to an average of

$2^{\circ} \mathrm{C}$ in 2050, either to Arab region extent (RICCAR 2013) clarified that in mid-century temperatures increase to $1.7^{\circ} \mathrm{C}-2.6^{\circ} \mathrm{C}$, while at the end of the 21 st century, it will increase to $3.2^{\circ} \mathrm{C}-4.8^{\circ} \mathrm{C}$, and a global extent (WMO 2011), it's report referred to global average temperature have varied on different time scales ranging from a few years to several decades.

The most values of Z-a/2 values of the MK Test >1.96, revealed an increasing trend in temperature and confirmed that significant positive trend with $95 \%$ confidence limit using a linear regression model. A positive value of (Sen's slope $=0.076$ ) of the mean annual indicates an increasing trend towards warmer years confirmed with an estimated by linear regression model. On a monthly time scale an increase of warm period starts from April to November noticed based on an increase in mean temperature, positive trend slope and positive values of anomalies during spring, summer and autumn. Therefore, significant increase trend of air temperature for this case study may be due to increased concentration of $\mathrm{CO} 2$ that leads to global warming caused via vehicles and thousands of motorcycles in city, the spread a lot of factories around the city, passive activity for human, and the uprooting of large numbers of trees to be used for fuel during the war, and the scarcity of green spaces around the city due to the lack of rain. Finally an increasing trend of temperature indicates the region is heading towards a warmer climate and vulnerable to climate change impact.

\section{Recommendations}

The results of the analysis indicate that in the study area, as in many other countries, the effects of climate change will be significant. Therefore, it is recommended to those concerned and decision-makers to take many actions in reducing exposure to the risks of climate fluctuations, such as building capacities, knowledge and relevant institutions to face crises from the consequences of the future climate, most important recommendations are provide climate data and the data about the impact of climate change on water resources; Agriculture; coastal areas etc.

\section{Declarations}

\section{Acknowledgements}

The authors are grateful to meteoblue AG Basel, Schweiz/Switzerlandthe for providing the requisite data, also express gratitude to Mr. Herrat Jassen.

\section{References}

Al-jibly AA (2018) The Climate Change Scenarios for Yemen for 2050. https://info.undp.org/docs/pdc/Documents/YEM/Climate Scenarios FinalDraft Report.pdf

Ali W, Alkadasi F (2011) UNDP: National Water Sector Strategy and Climate Change, Water Sector Strategy and Climate Change in Yemen. https://www.ye.undp.org/content/dam/yemen/E\&E/Docs/UNDP-YEM-CC and water sector VA in Yemen.pdf

Burn DH (1994) Hydrologic effects of climatic change in west-central Canada. J Hydrol 160:53-70. https://doi.org/10.1016/0022-1694(94)90033-7

Burn DH, Cunderlik JM, Pietroniro A (2004) Hydrological trends and variability in the Liard River basin/Tendances hydrologiques et variabilité dans le basin de la rivière Liard. Hydrol Sci J 49:53-67. https://doi.org/10.1623/hysj.49.1.53.53994

Da Silva RM, Santos CAG, Moreira M et al (2015) Rainfall and river flow trends using Mann-Kendall and Sen's slope estimator statistical tests in the Cobres River basin. Nat Hazards 77:1205-1221. https://doi.org/10.1007/s11069-015-1644-7

Dawood M (2017) Spatio-statistical analysis of temperature fluctuation using Mann-Kendall and Sen's slope approach. Clim Dyn 48:783-797. https://doi.org/10.1007/s00382-016-3110-y

Douabul A, Haddad AM (1999) The Red Sea and Yemen's Red Sea Environments; [In: Protection of Marine Ecosystems of the Red Sea Coast of Yemen. In: DouAbul A, Rouphael T, Marchant R (eds) 1st edn. Hassell. Assoc., AMSAT and UNOPS, pp 1-16.

https://www.researchgate.net/publication/261989117_The_Red_Sea_and_Yemen\%27s_Red_Sea_Environments

Douglas EM, Vogel RM, Kroll CN (2002) Impact of streamflow persistence on hydrologic design. J Hydrol Eng 7:220-227.

https://doi.org/10.1061/(ASCE)1084-0699(2002)7:3(220)

Elasha B (2010) Mapping of Climate Change Threats and Human Development Impacts in the Arab Region. Res Pap Ser UNDP, 2008.

https://www.researchgate.net/publication/248391569_Mapping_of_Climate_Change_Threats_and_Human_Development_Impacts_in_the_Arab_Region

EPA (2004) First National Report To the Convention on Biological Diversity, Ministry of Water and Environment,Environment Protection Authority (EPA), Yemen. https://www.cbd.int/doc/world/ye/ye-nr-01-en.pdf

Gilbert RO (1987) Statistical methods for environmental pollution monitoring. John Wiley \& Sons, https://www.osti.gov/servlets/purl/7037501

Hirsch RM, Alexander RB, Smith RA (1991) Selection of methods for the detection and estimation of trends in water quality. Water Resour Res 27:803-813.

DOI 10.1029/91WR00259

Page $7 / 13$ 
Jaagus J (2006) Climatic changes in Estonia during the second half of the 20th century in relationship with changes in large-scale atmospheric circulation. Theor Appl Climatol 83:77-88. https://doi.org/10.1007/s00704-005-0161-0

Jain SK, Kumar V (2012) Trend analysis of rainfall and temperature data for India. Curr Sci 37-49. https://www.academia.edu/2670819

Kendall M (1956) Rank Correlation Methods. Br J Stat Psychol 9:68-68. https://doi.org/10.1111/j.2044-8317.1956.tb00172.x

Lindström G, Bergström S (2004) Runoff trends in Sweden 1807-2002/Tendances de l'écoulement en Suède entre 1807 et 2002. Hydrol Sci J $49: 69-83$. https://doi.org/10.1623/hysj.49.1.69.54000

Mann H (1945) Non-parametric tests against trend. Econometrica 13:245-259. https://doi.org/10.2307/1907187

Mosmann V, Castro A, Fraile R et al (2004) Detection of statistically significant trends in the summer precipitation of mainland Spain. Atmos Res 70:43-53. https://doi.org/10.1016/j.atmosres.2003.11.002

NAPA (2008) Yemen: National Adaptation Programme of Action. https://unfccc.int/resource/docs/napa/yem01.pdf

Panda A, Sahu N (2019) Trend analysis of seasonal rainfall and temperature pattern in Kalahandi, Bolangir and Koraput districts of Odisha, India. Atmos Sci Lett 20:1-10. https://doi.org/10.1002/asl.932

RICCAR (2013) Arab Climate Change Assessment Report. 334. https://www.unescwa.org/publications/riccar-arab-climate-change-assessment-report

RoY (2001) Initial national communication under the United Nations framework convention on climate change. Republic of Yemen. Local Environment 487. https://unfccc.int/sites/default/files/resource/Yemen_INC.pdf

RoY (2013) Second National Communication Under The United Nations Framework Convention on Climate Change. Republic of Yemen.

https://unfccc.int/resource/docs/natc/yemnc2.pdf

Sen PK (1968) Estimates of the regression coefficient based on Kendall's tau. J Am Stat Assoc 63:1379-1389. https://doi.org/10.2307/2285891

Shadmani M, Marofi S, Roknian M (2012) Trend analysis in reference evapotranspiration using Mann-Kendall and Spearman's Rho tests in arid regions of Iran. Water Resour Manag 26:211-224. https://doi.org/10.1007/s11269-011-9913-z

Sneyers R (1990) On the statistical analysis of series of observations. World Meteorological organization, Geneva, Technical Note N 143 , U.D.C. 551.501.45, 192 p. https://doi.org/10.1016/0169-8095\%2893\%2990010-L

Sneyers R (1992) On the use of statistical analysis for the objective determination of climate change. Meteorol Zeitschrif 1:247-256.

https://doi.org/10.1127/metz/1/1992/247

Tabari H, Marofi S, Aeini A et al (2011) Trend analysis of reference evapotranspiration in the western half of Iran. Agric For Meteorol 151:128-136.

https://doi.org/10.1016/j.agrformet.2010.09.009

UNEP/ROWA (2015) Regional Coordination Mechanism (RCM) Issues Brief for the Arab Sustainable Development Report Climate Change in the Arab Region. http://css.escwa.org.lb/SDPD/3572/Goal13.pdf

WMO (2011) WMO Statement on the Status of the Global Climate in 2010, WMO-No.1074. World Meteorological Organization, Geneva

WorldBank (2010) Yemen - Assessing the Impacts of Climate Change and Variability on the Water and Agricultural Sectors and the Policy Implications. The World Bank. https://ideas.repec.org/p/wbk/wboper/2943.html

Yue S, Hashino M (2003) Long term trends of annual and monthly precipitation in Japan. JAWRA J Am Water Resour Assoc 39:587-596.

https://doi.org/10.1111/j.1752-1688.2003.tb03677.x

\section{Figures}




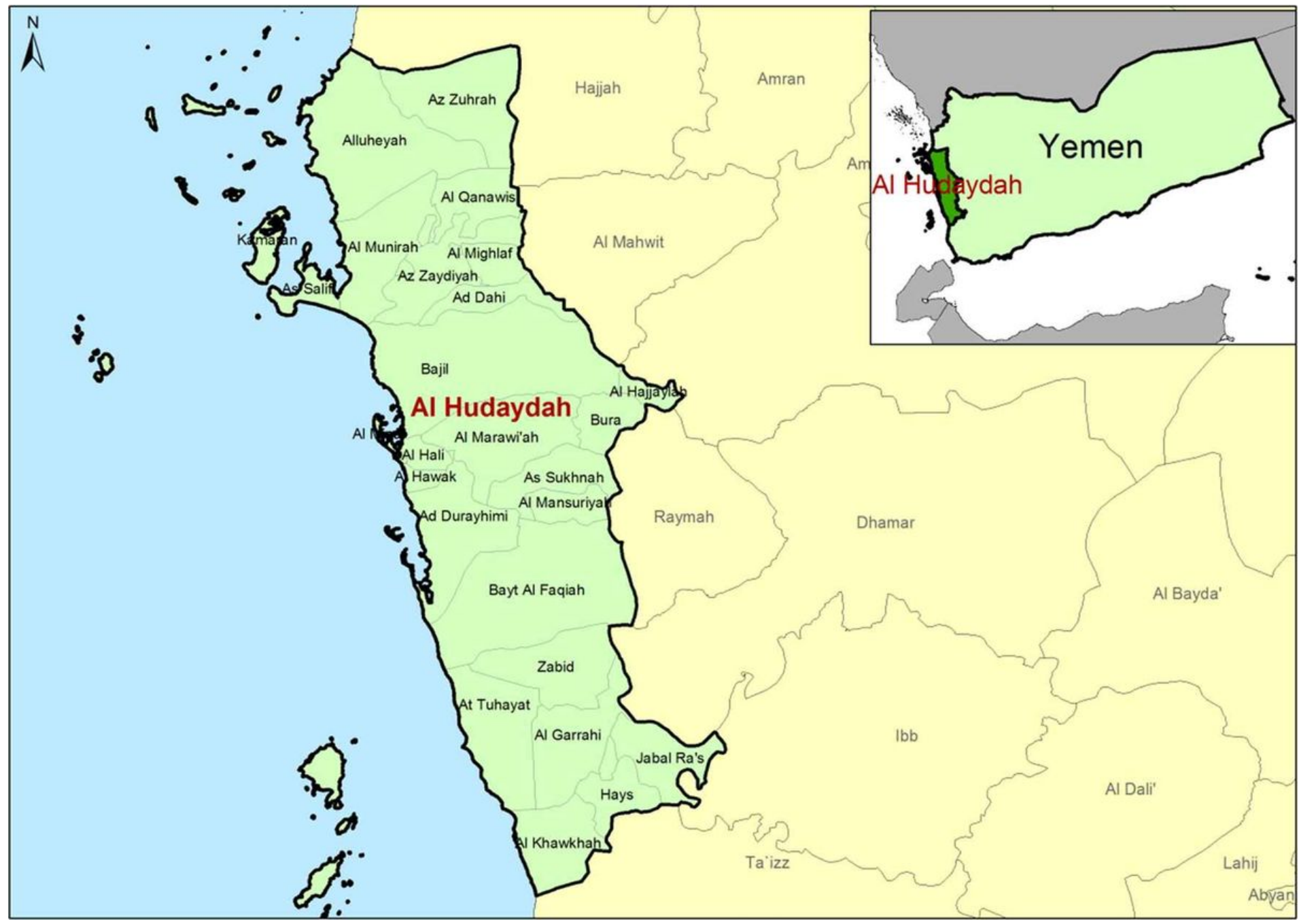

Figure 1

Study Area (Al-Hodeidah Governorate- Hodeidah City-Yemen) 

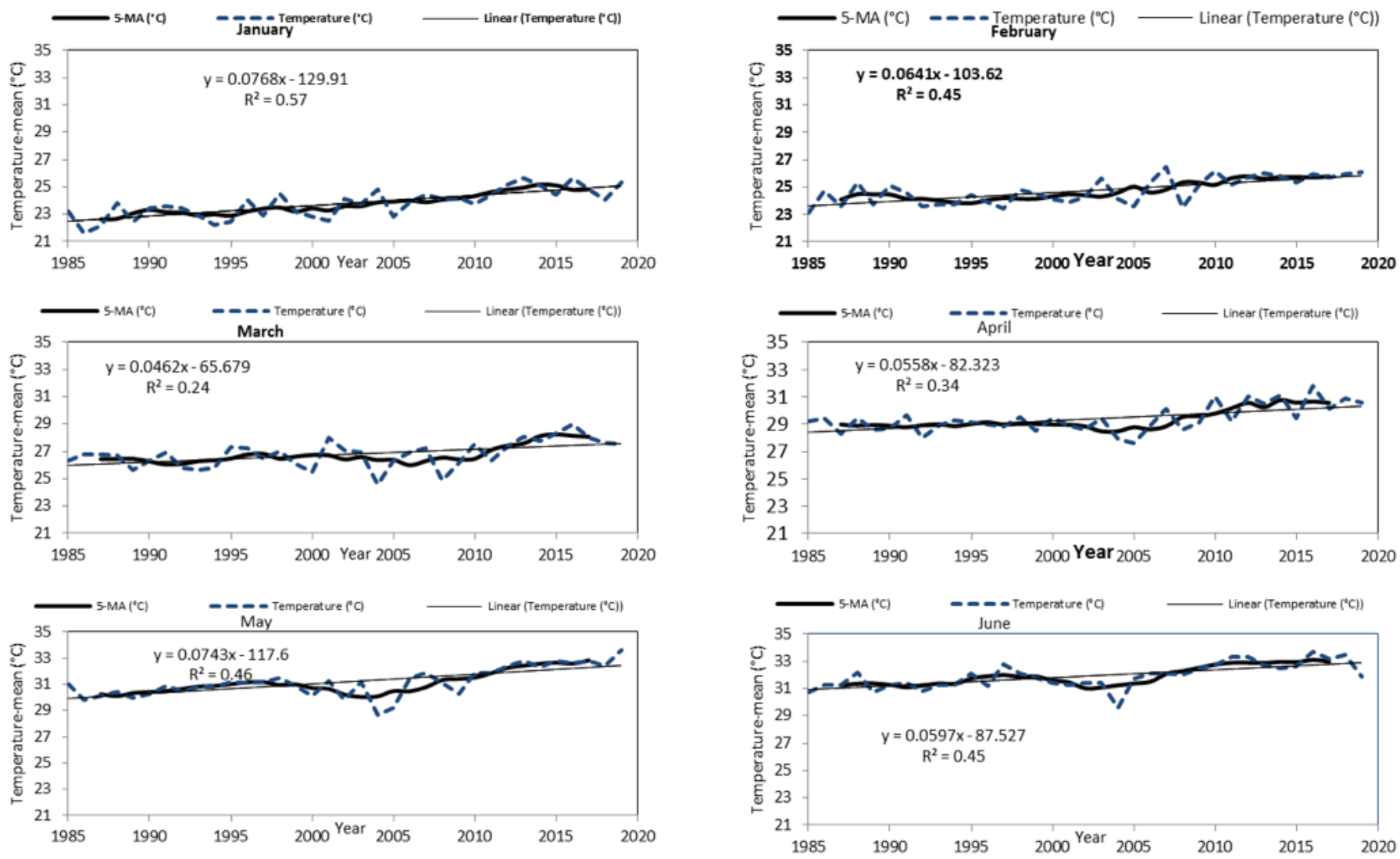

Figure 2

Time series fluctuations (blue dotted line), 5-moving averages (black bold line), linear trends (thin line) on a monthly time scales throughout (January to June) for the period (1985-2019).
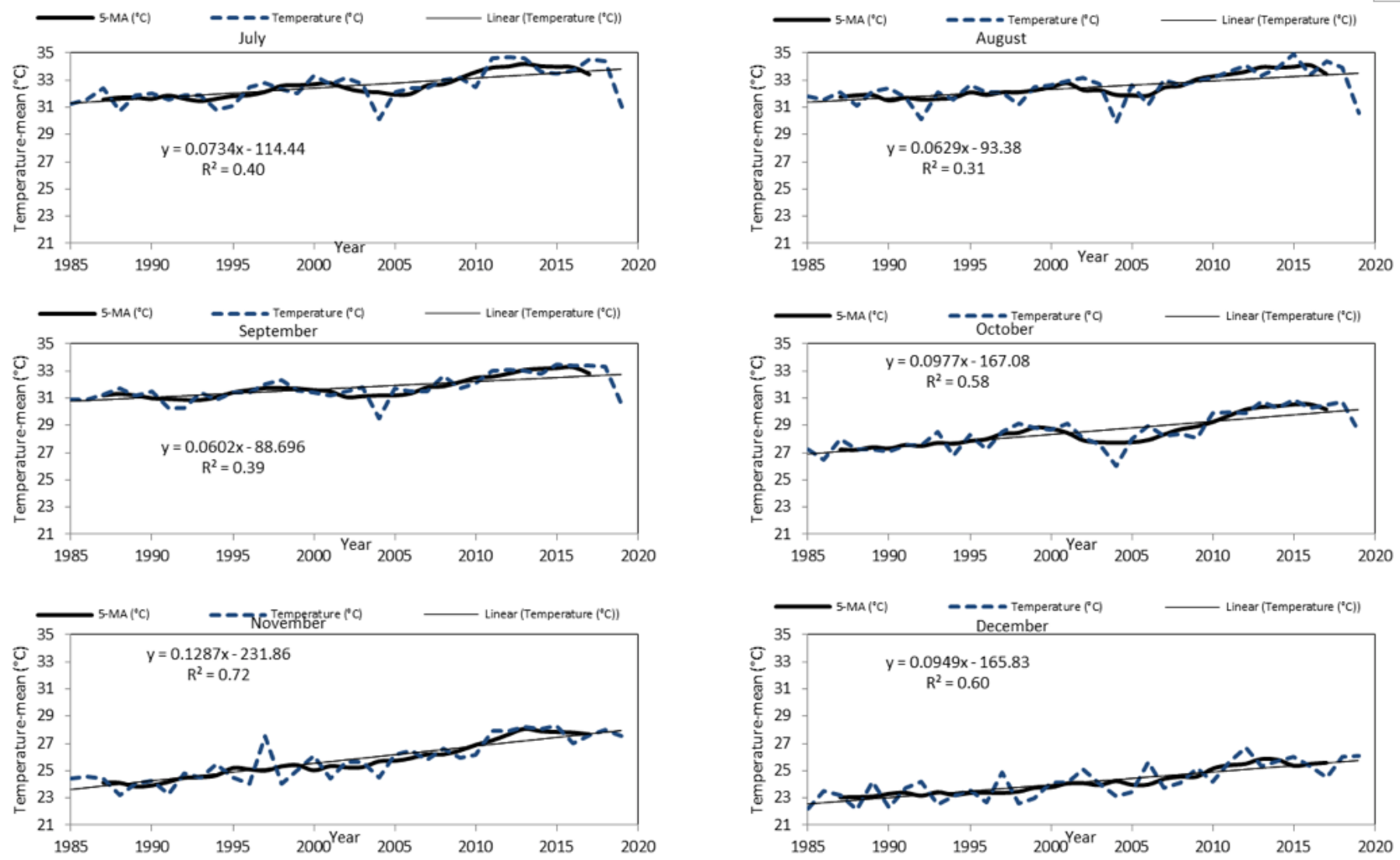
Figure 3

Time series fluctuations (blue dotted line), 5-moving averages (black bold line), linear trends (thin line) on a monthly time scales throughout (Jul to December) for the period (1985-2019).
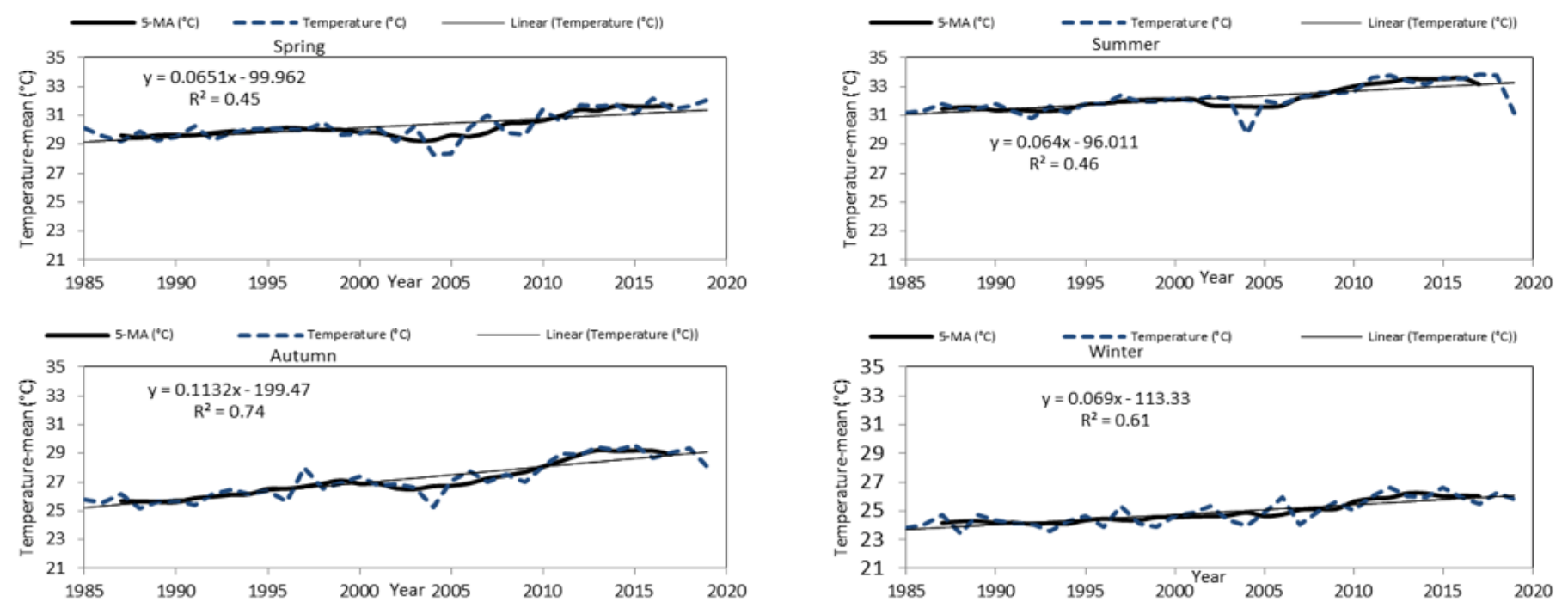

Figure 4

Time series fluctuations (blue dotted line), 5-moving averages (black bold line), linear trends (thin line) on a seasonal time scales throughout (Spring; Summer; Autumn and Winter) for the period (1985-2019).
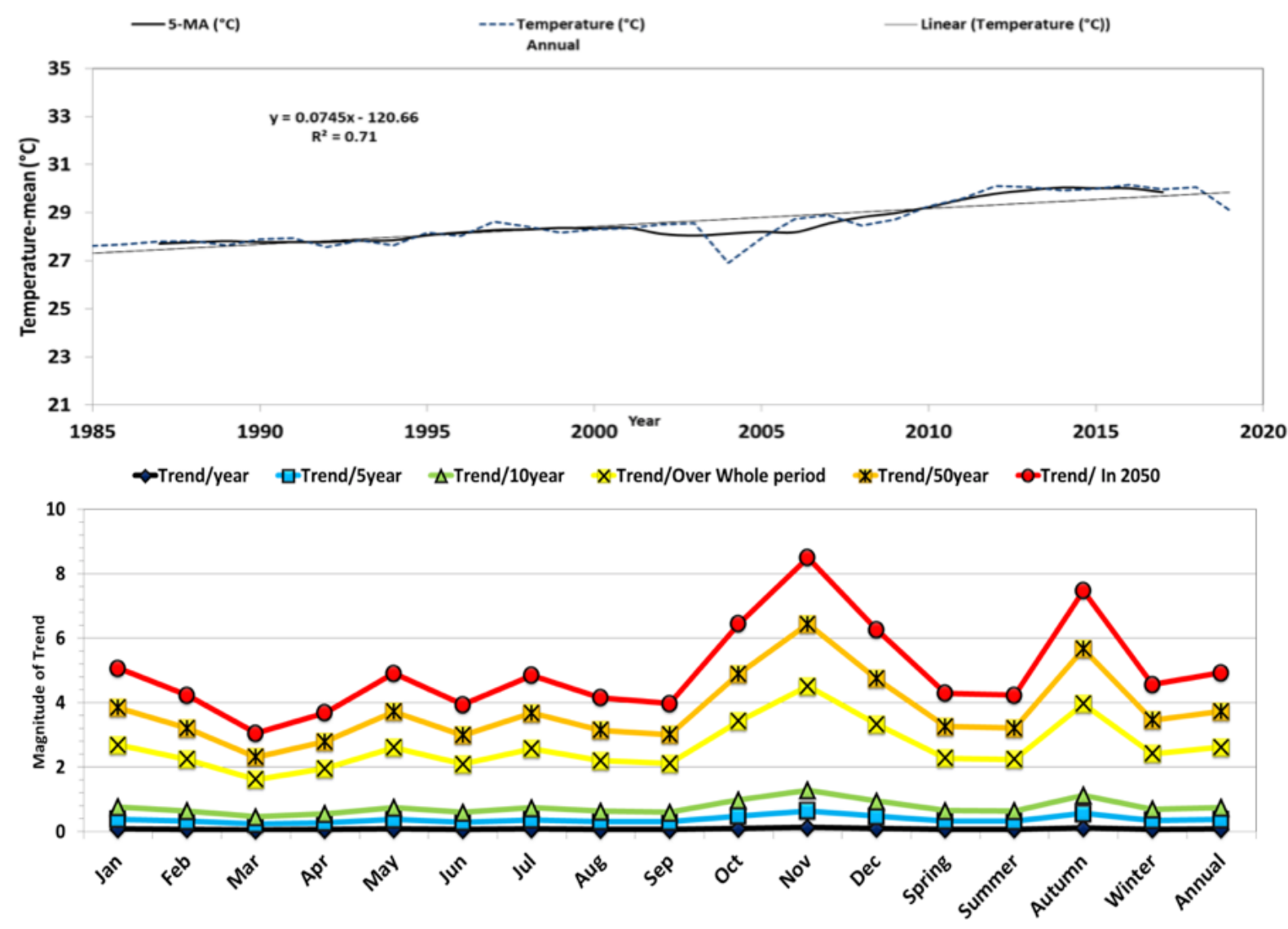

Figure 5

a. Time series fluctuations (blue dotted line), 5-moving averages (black bold line), linear trends (thin line) on annual time scales \& b. The magnitude of trend on a monthly, seasonal and annual time scales for the period (1985-2019). 

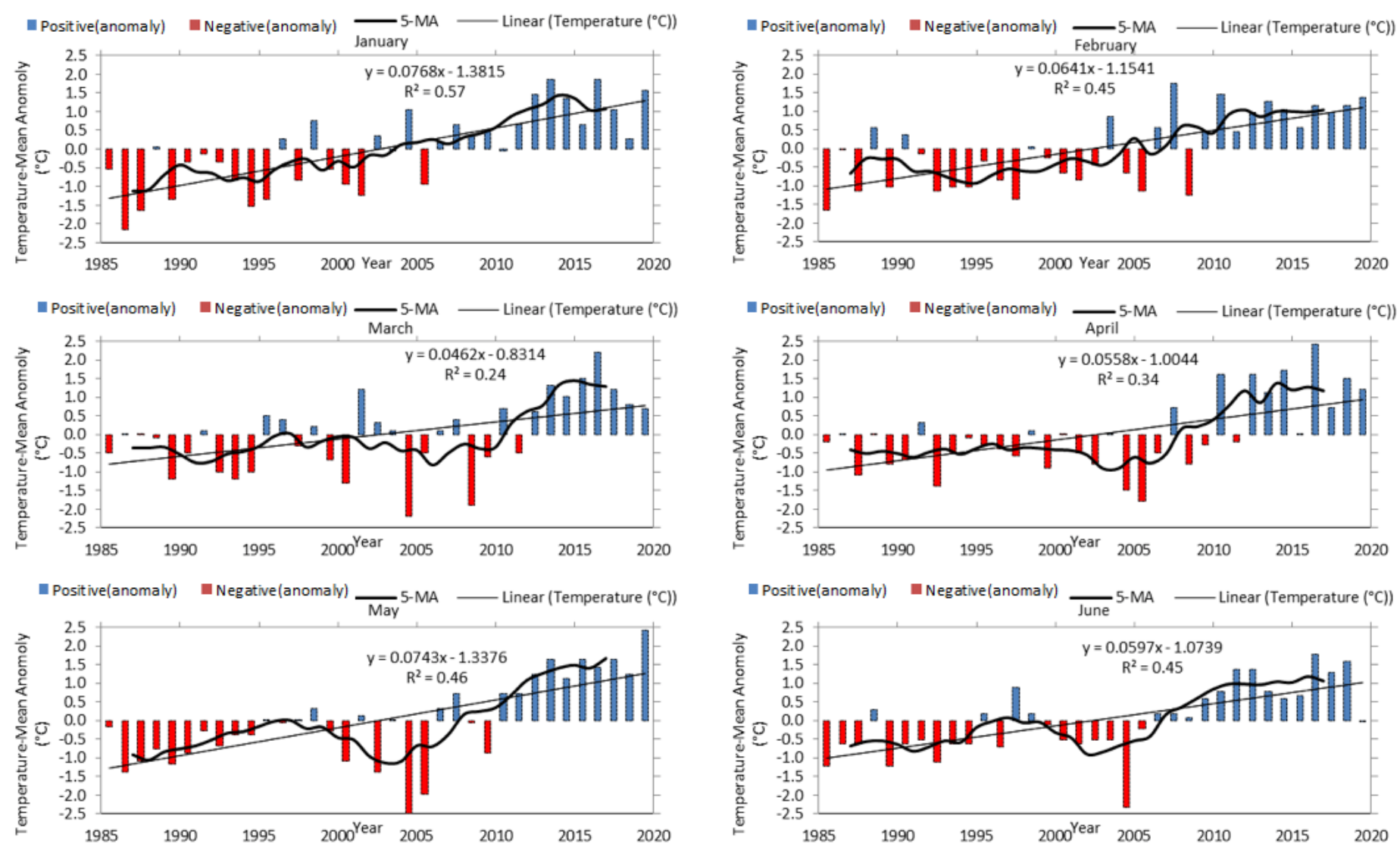

Figure 6

Mean air temperature anomalies (Positive blue bar/negative red bar), 5-moving average (black bold line) and linear trends (thin line) on a monthly time scale throughout (January to June) for the period (1985-2019).
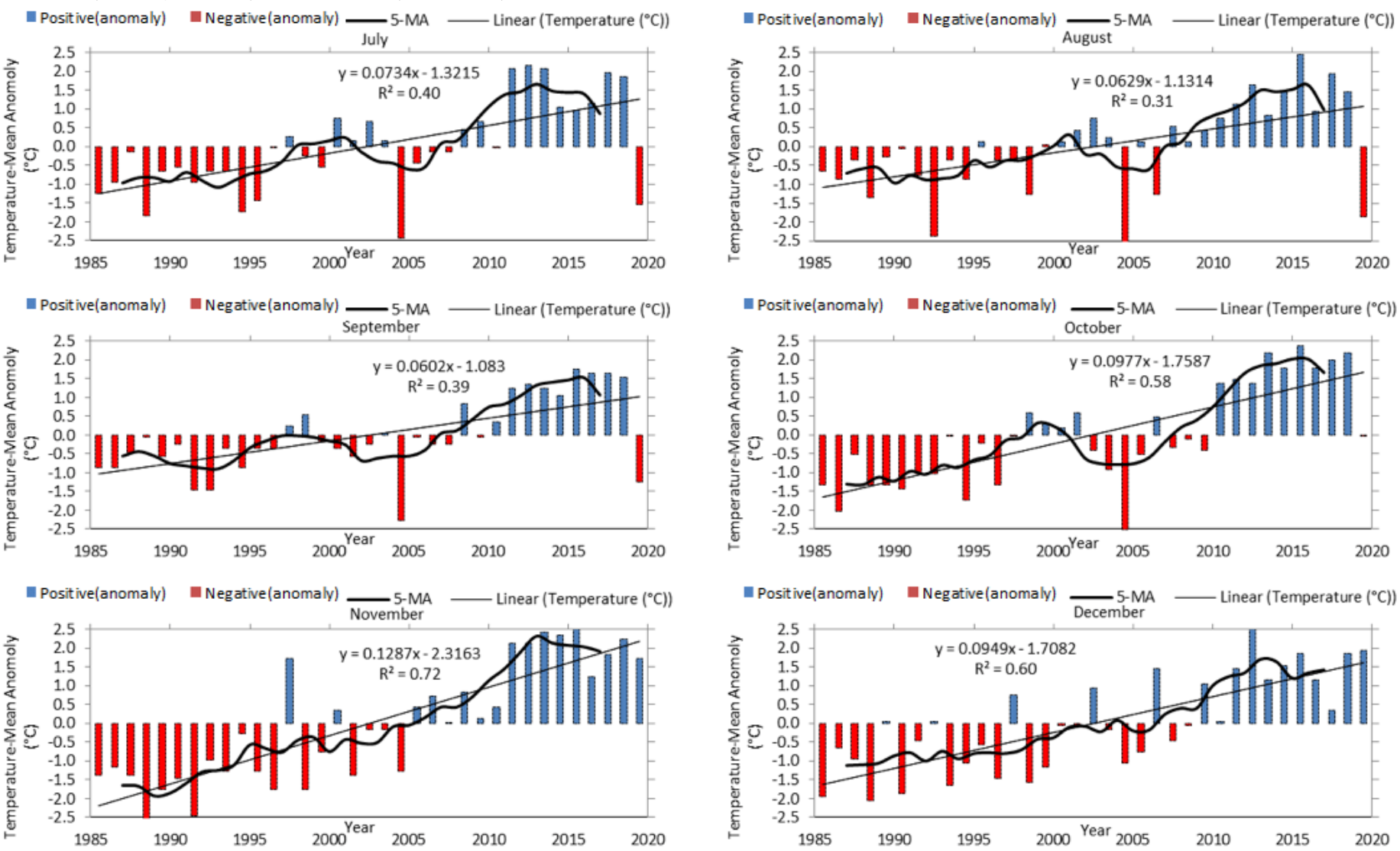
Figure 7

Mean air temperature anomalies (Positive blue bar/negative red bar), 5-moving average (black bold line) and linear trends (thin line) on a monthly time scale throughout (Jul to December) for the period (1985-2019).
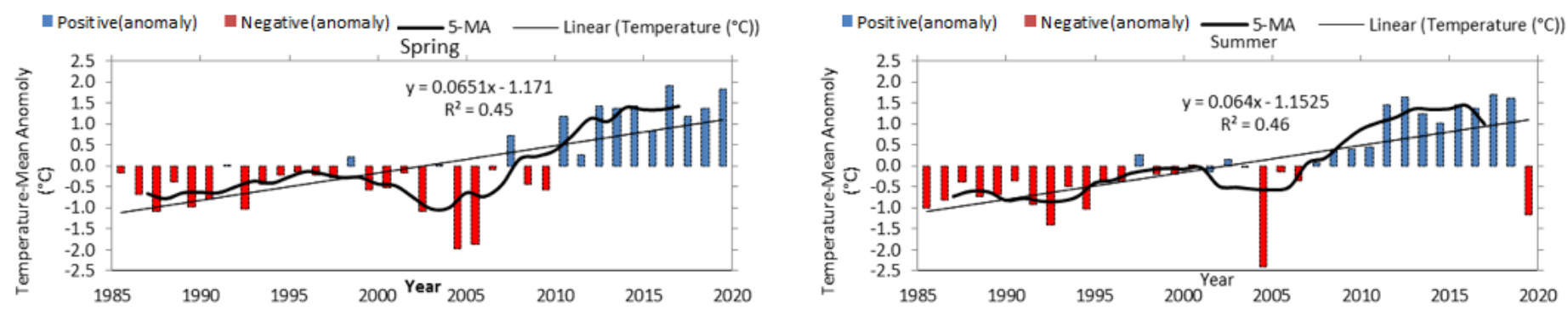

W Positive(anomaly) Negative(anomaly)

E Positive(anomaly) Negative(anomaly) -
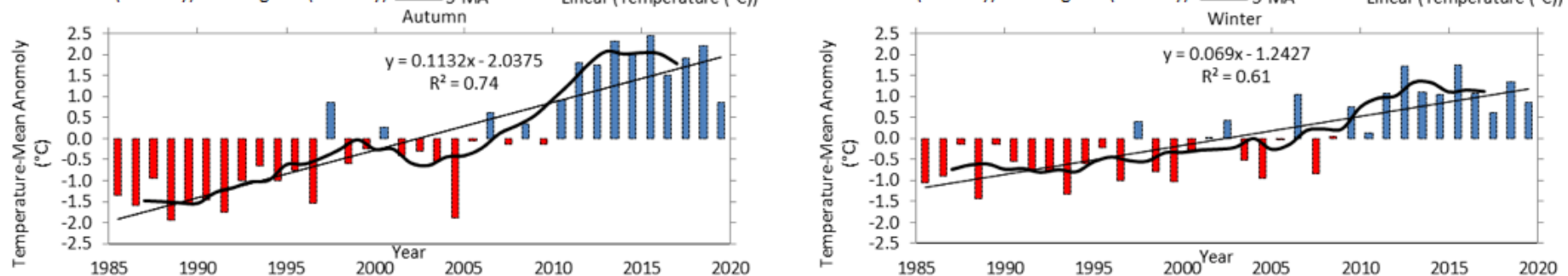

Figure 8

Mean air temperature anomalies (Positive blue bar/negative red bar), 5-moving average (black bold line) and linear trends (thin line) on a seasonal time scale throughout (Spring; Summer; Autumn and Winter) for the period (1985-2019). 